\title{
3DVARを用いた温帯低気圧時の海上風追算手法の精度向上
}

\section{Improvement of the precision of hindcasted coastal sea surface wind by 3DVAR at extratropical cyclone}

\author{
中野俊夫 ${ }^{1} \cdot$ 橋本典明 $^{2} \cdot$ 上原謙太郎 ${ }^{3} \cdot$ 松浦邦明 $^{4} \cdot$ 川口浩二 ${ }^{5}$ \\ Toshio NAKANO, Noriaki HASHIMOTO, Kentaro UEHARA \\ Kuniaki MATSUURA and Koji KAWAGUCHI
}

\begin{abstract}
It is of great importance to hindcast sea surface winds accurately under extratropical cyclone conditions. However, accurate wind hindcasting on sea surface is sometimes very difficult since the data resolution is not enough to represent the extratropical cyclone system, and is especially not so before 1996. In this study, therefore, we assimilate mean-sea-level barometric pressure data into the computations with a meso-scale meteorological model to improve the hindcasting accuracy of coastal sea surface winds by 3Dimentional Variational Assimilation scheme. As a result, we can express the movement, strength and detail structure of extratropical cyclone by using 3DVAR, and hindcast accuracy of coastal sea surface wind is improved.
\end{abstract}

\section{1. はじめに}

防波堤や護岸の設計をする上で，数十年における台風 や温帯低気圧による沿岸の強風や波浪・高潮を精度よく 再現することは, 重要な問題である。近年, 台風に関し ては，数值予報モデルに台風ボーガス（大澤ら，2001） や4次元デー夕同化を用いることで, 改善が図られてき た（例えば，中野ら，2005）。しかし, 温帯低気圧に関し ては, 過去事例を対象とする場合, 特に解析值の整備が 十分でない1996年以前では, 入力值となる客観解析值の 解像度が粗いため, (1)温带低気圧が弱く表現されている, (2)温帯低気圧の細かな構造が表現できていない, という 問題があり, 海上風の追算精度に影響を与えてきた.

そこで, 台風ボーガスを温帯低気圧に適用することで, 温帯低気圧の構造を再現する試みなどが行われてきた (金ら，2005）。しかし, 温帯低気圧は, 海水面から供給 される潜熱をエネルギーとして発達する熱帯低気圧や台 風と違い, 寒気と暖気が混合し, 位置エネルギーが運動 エネルギーに転換されることで発達する. そのため, 台 風とは熱構造や発生メカニズムなどが異なり, 同一に扱 うことは，困難であった。

一方，デー夕同化手法は，これまで予報変数と線形な 観測データを同化する手法（最適内扦法など）が主流で あったが, 近年では, 予報変数と非線形の観測デー夕を
変分法により同化できる3DVAR（3-Dimentional Variational Data Assimilation）が実用可能になってきた (露木ら，2008). この3DVARは, (1)予報変数と非線形 で計算に利用できなかったデー夕（GPS 可降水量など） を同化した精度向上の研究（杉本，2008）や，(2)現業予 報など，に利用されてきた。 そのため, 近年の気象デー 夕は, 精度が向上し, 温帯低気圧の構造を十分に表現で きるようになっているが, 過去の気象デー夕は, 解像度 も粗く，精度は十分とは言えない.

そこで, 本研究では, 気象データの解像度が十分でな い過去の温帯低気圧事例において, 高層ゾンデデータや, 予報変数と非線形の関係である海面更正気圧デー夕を 3DVARで同化することにより, 海上風の追算精度の向 上を図った。

\section{2. 計算手法}

\section{（1）数値予報モデル}

数值予報モデルには，メソ気象モデルWRF（Weather Research and Forecasting Model）を用いた. 水平格子間隔 は, 温帯低気圧スケールの擾乱を解像できる格子間隔と して $15 \mathrm{~km}$ とし，200×170の領域を設定した（図-1）.

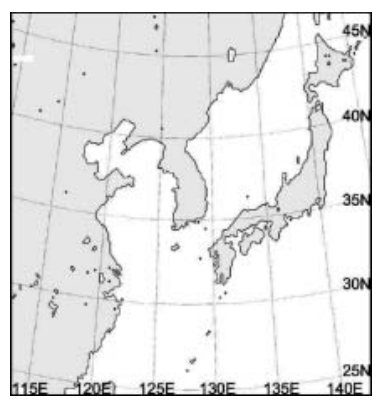

図-1 計算領域図 
鉛直方向の気圧準拠座標（ $\sigma$ 座標）については, 地表 から $100 \mathrm{hPa}$ まで 32 層を設定し, 最下層を $\sigma=0.997$ として, $800 \mathrm{hPa}$ より下層の大気境界層内に 12 層を集中させた. 気 象場の初期 - 境界值には, 2.5 度格子の NCEP客観解析值 (以下, NCEPデー夕), 海面水温には 1 度格子のOISSTを 与えた.

\section{(2) 3DVAR}

3DVARモデルには，メソ気象モデルWRFに対して開 発された変分法に基づくデータ同化システムWRF-Var （Barkerら，2004）を用いた. WRF-Varでは，以下のコ スト関数

$$
\begin{aligned}
J(X)=\frac{1}{2}( & \left.X-X_{b}\right)^{T} B^{-1}\left(X-X_{b}\right) \\
& +\frac{1}{2}\left(Y-Y^{o}\right)^{T} R^{-1}\left(Y-Y^{o}\right)
\end{aligned}
$$

が最小となるモデル変数の最適值ベクトル $X$ を共役勾配 法により探索する.ここで $X_{b}$ は, モデル変数の第一推定 值ベクトル， $Y^{o}$ は観測值ベクトルである， $Y$ は，モデル 変数 $X$ が観測演算子 $H$ により観測值の単位や量に変換さ れたもの $(Y=H(x))$ である. 添え字 $T$ は行列の転置を意 味する. $R, B$ はそれぞれ, 観測值の誤差共分散行列およ び背景誤差共分散行列である.

観測值は，天気図からトレースした海面更正気圧デー 夕と高層ゾンデデータを使用した。海面更正気圧データ の観測演算子 $H$ は, 式（2）に示す気柱の鉛直積分によ って得られる值である。ここで $P_{0}$ は海面更正気圧, $g$ は 重力加速度, $R$ は乾燥空気の気体定数, $T$ は気温である.

$$
P_{0}=\exp \left(\int \frac{g}{R T} d z\right)
$$

最適内挿法やナッジングでは, 風速や気温, 高度など 予報変数と線形の関係にある観測值しか同化することが できなかった。しかし，3DVARでは観測演算子を用い ることで予報変数と線形でない観測值, 海面更正気圧も 同化でき，このデータを同化することで，全高度におけ る, 風, 気温, 高度場の修正を行うことができる，本研 究では, 海面更正気圧デー夕は, NCEPデー夕では表現 できていない温帯低気圧の強度や詳細な構造を修正する 目的で使用した。高層ゾンデデータは, 時間積分によっ て生じる高層気象場の誤差を修正する目的で使用した。

観測值の誤差共分散行列は，表現誤差・観測誤差から なる観測值固有の值であり，統計データを用いた。背景 誤差共分散行列は, NMC (National Meteorological Center) 法から推定した（Parrishら，1992）。NMC法は，ある時 刻に対する24時間予測值と 12 時間予測值の差を一定期 間, 蓄積して, 統計解析に用いる手法である。本研究で は, 計算対象時刻の前後 1 週間の計算值から求めた.

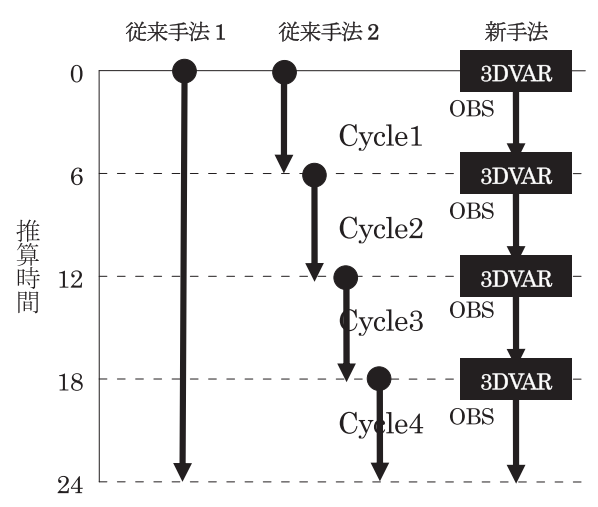

図-2 各手法の計算システムの模式図

\section{(3) 計算システム}

従来の計算システムと，データ同化を行った場合の計 算システムの違いの模式図を図-2に示す。従来では, 24 時間の追算を行う場合，一般的には以下の 2 手法がとら れてきた。

(1) 24 時間の連続追算計算を行う（従来手法 1 ).

(2) 6 時間ごとに初期・境界值を変更して，6時間の追算 計算を行う（従来手法2）.

しかし，従来手法1の場合は，計算時間が長くなるに つれて, 精度が劣化していくという問題があり, 従来手 法2の場合は，計算時間が短いため初期值の影響が大き く，その精度に依存する，また，各Cycleの追算結果は 独立で連続性がない, などの問題があった。

新手法は，上記の問題を解決するため，3DVARを用 いた解析予報サイクルを構築した。この手法では，まず， 初期時刻のNCEPデー夕を第一推定值（デー夕同化前の 值）として，海面更正気圧を同化し，解析值（データ同 化後の值）を作成し，6時間計算を行った。次に，その 6 時間後の計算值を第一推定值として, 海面更正気圧デー 夕，高層ゾンデデータを同化して解析值を作成した。以 後は，同様のサイクルを組み，24時間の計算（6時間 $\times$ 4Cycle）を行った。このようなサイクルを組むことで， 計算によって生じる䛊差を6時間ごとに修正でき，また， 計算值・観測值の持つ情報を，次 Cycleに引き継ぎ，時 間の下流に伝播させることができる.

\section{3. 従来手法と新手法の比較}

従来手法と新手法の比較を二つ玉低気圧が日本に接近 した 2 事例を対象に行った。二つ玉低気圧とは，狭い地 域に二つの低気圧が近接している状態であり，細かな構 造を持っているため, 従来手法では, その構造を表現す ることは困難であった。

（1）事例1（初期時刻：1991年4月 18 日9時）

1991年4月 18 日9時の天気図を図-3に示す。この日は, 


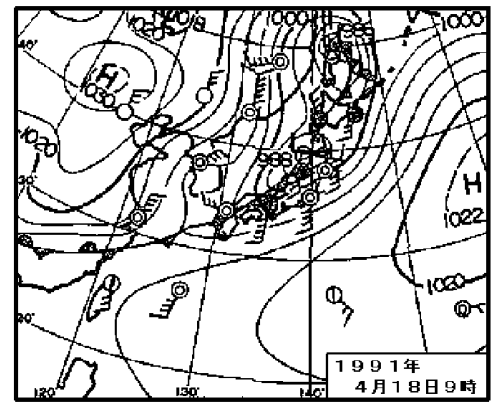

図-3 計算対象日の天気図（1991年4月18日9時）

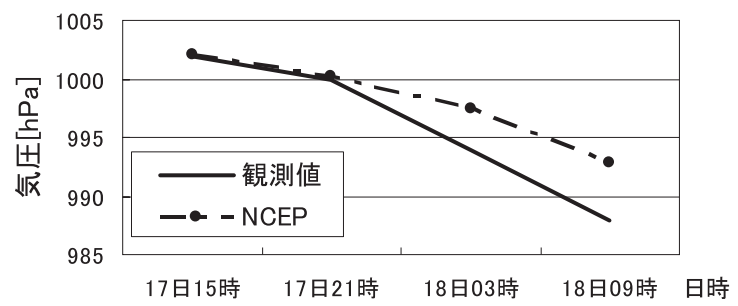

図-4 海面更正気圧の極小值の時系列変化

北海道北部に中心気圧 $986 \mathrm{hPa}$ の強い低気圧, 東北地方に 中心気圧 $988 \mathrm{hPa}$ の小さい低気圧が存在する二つ玉低気圧 の構造であった。本研究では, 東北地方の低気圧に着目

\section{して検証を行った.}

東北地方の低気圧の，観測值と NCEPデー夕における 海面更正気圧の極小值の時系列変化を図-4に示す. NCEPデータでは，17日 15 時には $1002 \mathrm{hPa}$ と観測值と同 程度の值であったが，東北地方に近づくにつれ，誤差が 大きくなり, 東北地方にもっとも接近した 18 日9時には, $5.2 \mathrm{hPa}$ の誤差が生じていた。これは, 本事例では, NCEPデータの解像度が十分でないため, 低気圧の強度 を表現できていなかったことが原因と考えられる.

以下では, Cycle3の初期（1991年4月18日3時）にお ける3DVARについて示す.

当該時刻の天気図の海面更正気圧を図-5に，同化前と 同化後の海面更正気圧と $10 \mathrm{~m}$ 高度風速を図-6に示す。な お, 第一推定值（デー夕同化前の值）は, 前サイクル （Cycle2）の6時間計算值とした。天気図では，低気圧の 中心が隠岐の島の北東に存在していたが，同化前は，低 気圧の中心は隠岐の島の北に存在しており, 南西に位置 ずれを起こしていた，一方, 天気図の海面更正気圧デー タをトレースし，52000点の観測值として3DVARを行っ たデー夕同化後の結果では, 低気圧の中心は, 天気図と 同様に隠岐の島の北東に位置しており，デー夕同化によ って, 低気圧の中心位置が, 修正されたことが分かる. また，海面更正気圧を同化することにより，気圧と地衡 風の関係にある風向風速も修正された.

デー夕同化による, 海面更正気圧と $10 \mathrm{~m}$ 高度風速の修

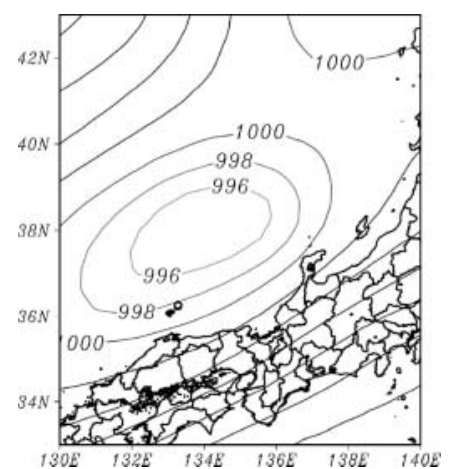

図-5 天気図の海面更正気圧（実線，単位 $\mathrm{hPa}$ )

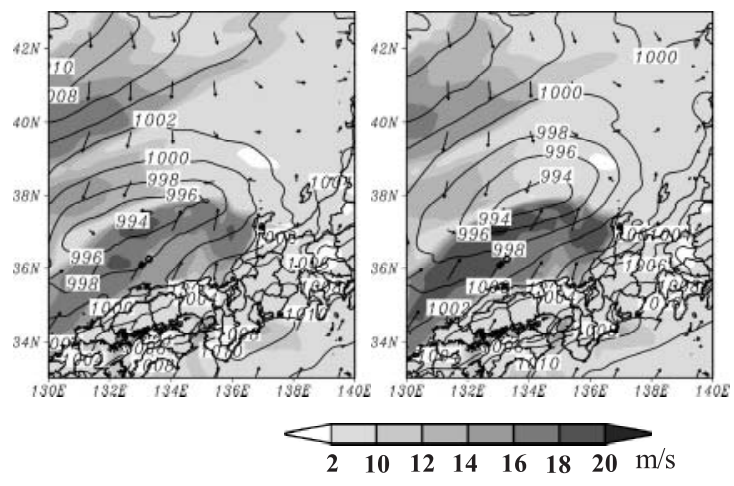

$\begin{array}{ll}\text { (a) 同化前 } & \text { (b) 同化後 }\end{array}$

図-6 同化前と同化後の海面更正気圧（実線, 単位：hPa）と $10 \mathrm{~m}$ 高度風速（陰影部，単位： $\mathrm{m} / \mathrm{s}$ )

正量を図-7に示す．海面更正気圧の修正量は，低気圧の 中心付近で最大となり，4.8hPaの修正量であった。これ は, 低気圧の中心付近で, 第一推定值と観測值の差が, もっとも大きかったためである，風速の修正量は，低気 圧の南西付近でもっとも大きく, $2.6 \mathrm{~m} / \mathrm{s}$ であった。 これ は, 気圧の修正量の傾度が, 低気圧の南西でもっとも大 きかったため, 地衡風の関係から風の修正量が大きくな ったと考えられる。

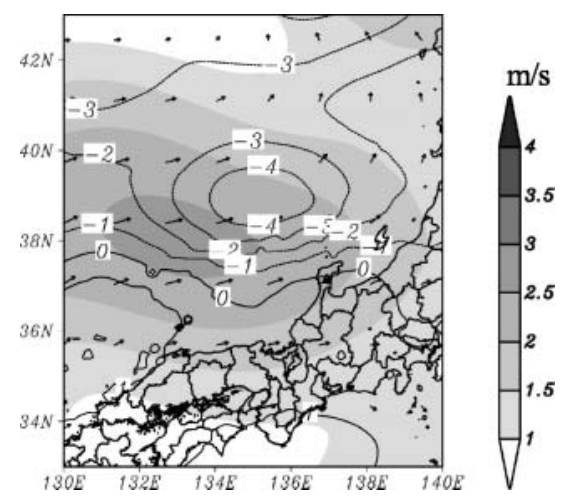

図-7 海面更正気圧（実線, 単位： $\mathrm{hPa}$ ）と $10 \mathrm{~m}$ 高度風速（陰 影部, 単位： $\mathrm{m} / \mathrm{s}$ ) の修正量 


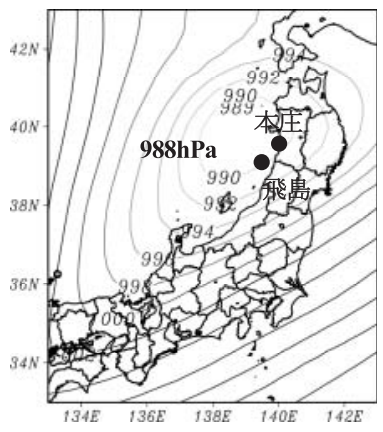

(a) 天気図

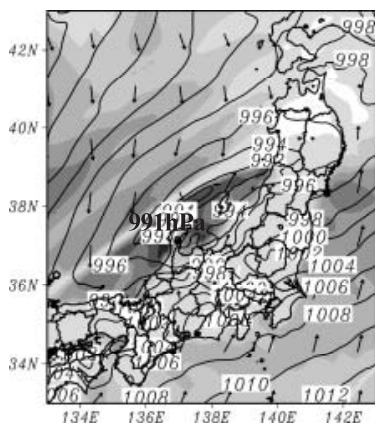

(b)従来手法 1

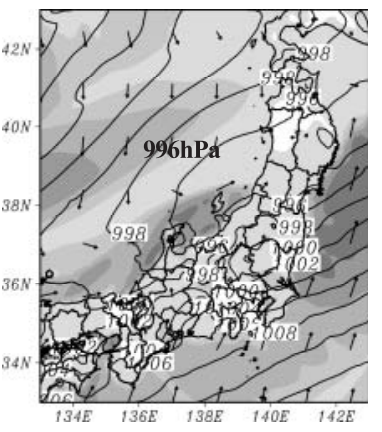

(c) 従来手法 2

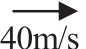

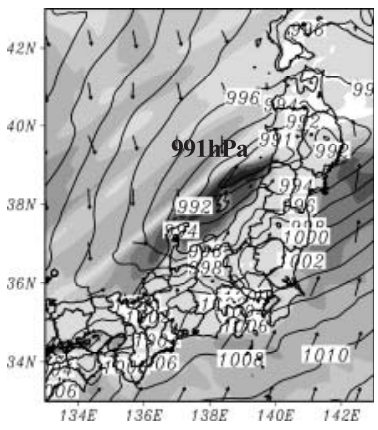

(d) 新手法

図-8 各手法の $10 \mathrm{~m}$ 高度風速（陰影部，単位： $\mathrm{m} / \mathrm{s}$ ） と気圧（実線，単位：hPa）分布（1991年4月 18日 9時）

上記 Cycle3 のデー夕同化の効果を検証するため, 従来 手法 1 の 18 時間計算值, 従来手法 2 , 新手法の Cycle3 の 6 時間計算值である 1991 年 4 月 18 日9時の $10 \mathrm{~m}$ 高度風速, 海面更正気圧分布を図-8に示す。

当該時刻では，天気図の低気圧の中心は，男鹿半島の 南西にあり，中心気圧が $988 \mathrm{hPa}$ であった。従来手法 1 は, 中心気圧は $991 \mathrm{hPa}$ であったが，低気圧の中心が佐渡島付 近に計算されており, 南西に位置ずれを起こしていた。 従来手法 2 は, 従来手法 1 と比較して, 低気圧の中心位 置の計算精度は, やや改善しているものの, 中心気圧が 996hPa と, 誤差が大きかった. 以上のように, 従来手法 では，積分時間を長くすると，低気圧の位置に誤差が生 じ，積分時間を短くすると低気圧の中心気圧が過小評価 になるというトレードオフの問題があり, 追算精度に影 響を与えていた。一方, 新手法は, 中心気圧が991hPaで, 低気圧の中心位置も男鹿半島の南西に存在しており, 低 気圧の中心位置・強度, ともに再現性が高かった。これ は，3DVARを行うことで, 海面更正気圧デー夕の情報 を追算計算に取り込むことができたために，追算精度が 向上したと考える.

本事例において, 低気圧が通過したAMeDAS 地点, 本 庄と飛島に抢ける風速と風向の時系列変化図を図-9に示 す. 2 地点の観測值をみると, 本庄では，4月18日9時に 最大風速 $16.0 \mathrm{~m} / \mathrm{s}$, 飛島では 4 月 18 日 10 時に最大風速 $14.4 \mathrm{~m} / \mathrm{s}$ を記録していた。本庄では, 従来手法 1 , および 従来手法 2 ともに, $16.0 \mathrm{~m} / \mathrm{s}$ の強風を再現することができ なかったが, 新手法では, $16.9 \mathrm{~m} / \mathrm{s}$ と観測值に近い風速を 再現していた。 また, 飛島においても, 新手法は, 最大 風速 $14.0 \mathrm{~m} / \mathrm{s}$ を計算しており, 従来手法と比較して, 再 現性が高かった。

海岸に近い AMeDAS の 5 地点（本庄, 飛島, 泊, 輪島, 石巻）で風速の相関を取ったところ, 従来手法 1 は 0.64 ,

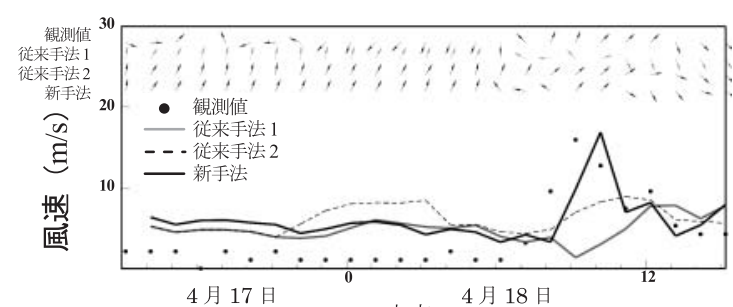

(a) 本庄

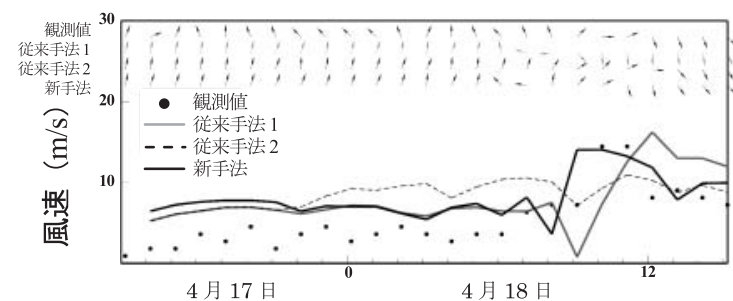

(b) 飛島

図-9 各手法による風向風速の経時変化 （風向：上部ベクトル）

従来手法 2 は 0.65 , 新手法は 0.75 と, 新手法がもっとも 相関係数が高かった。

\section{（2）事例2（1978年3月 1 日 9 時）}

従来手法 1 の 12 時間計算值, 従来手法 2 , 新手法の Cycle2 の 6 時間計算值である 1978年 3 月 1 日 9 時の $10 \mathrm{~m}$ 高 度風速，海面更正気圧分布を図-10に示す。

当該時刻は, 低気圧の中心が根室の南に存在していた が，もうひとつ，下北半島の東海上にも，小さな低気圧 の中心が存在する二つ玉低気圧の構造であった．計算結 果を見ると, 従来手法 1 , 従来手法 2 ともに, 根室の南 の低気圧は計算することができていたが，下北半島の東 海上の低気圧を計算することはできていなかった。これ は，NCEPデー夕の解像度が粗いために，このような低 気圧の細かな構造を表現することができなかったためと 考える。 


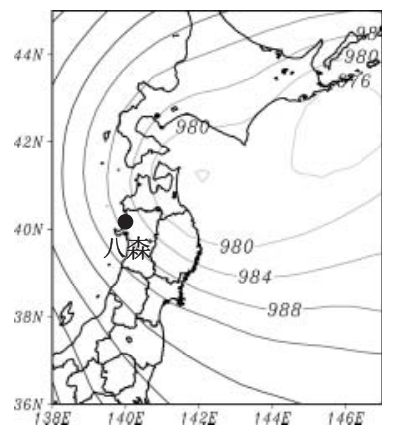

(a) 天気困

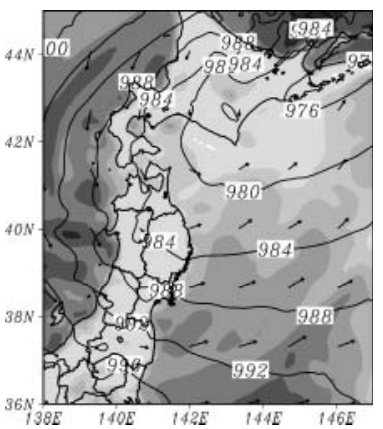

(b)従来手法 1

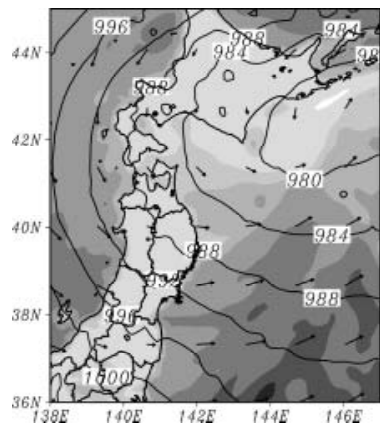

(c) 従来手法 2

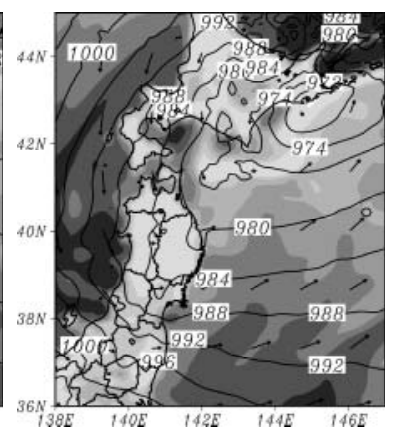

(d) 新手法
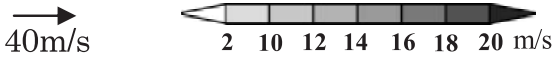

図-10 各手法の $10 \mathrm{~m}$ 高度風速（陰影部，単位： $\mathrm{m} / \mathrm{s}$ ） と気圧（実線，単位：hPa）分布（1978年3月1日9時）

一方, 新手法では, 根室の南の低気圧に加えて, 下北 半島の東海上に，低気圧の中心が表現されていた，その ため, 青森県や秋田県北部海岸沿いでは, 従来手法と比 較して, 風速が強くなっていた.

本事例において，低気圧が通過したAMeDAS地点，八 森に抒ける風速の風向時系列変化図を図-11に示す。観 測值では，3月 1 日 10 時に $20.2 \mathrm{~m} / \mathrm{s}$ の強風を観測していた が, 従来手法 1 抢よび従来手法 2 はいずれも $13.3 \mathrm{~m} / \mathrm{s}$ と過 小評価をしていた。一方, 新手法は, $17.8 \mathrm{~m} / \mathrm{s}$ と観測值に 近い值を計算していた。これは，デー夕同化を行うこと により, 海面更正気圧から, 低気圧の詳細な情報を取り 入れることが可能となり, その結果, 二つ玉低気圧の構 造の再現性, 風速の追算精度が向上したと考えられる。

海岸に近い AMeDASの7地点 (八森, 深浦, 相川, 能 代, 苫小牧, 秋田, 松前) で相関を取ったところ, 従来 手法 1 は 0.64 , 従来手法 2 は 0.56 , 新手法 0.68 と, 新手法 がもっとも相関倸数が高かった。

\section{4. 結語}

本研究では, 温帯低気圧による沿岸の局地的な強風の 追算精度を向上するため, 3DVARを用いて, 海面更正 気圧データや高層ゾンデデータの同化を行った．主な結 果は, 以下のようである.

（1）3DVARを用いることで，NCEPデータでは解像度が 粗いために, 表現することができなかった低気圧の強 度や動きを表現することができる（事例 1)。

（2）3DVARを用いることで, NCEPデータでは, 解像 度が粗いために表現することのできなかった，二つ玉 低気圧などの細かな構造を表現することができる（事 例2).

ただし，本研究では，事例解析にとどまっていること から，今後は様々な事例で精度検証を行い，一般性のあ

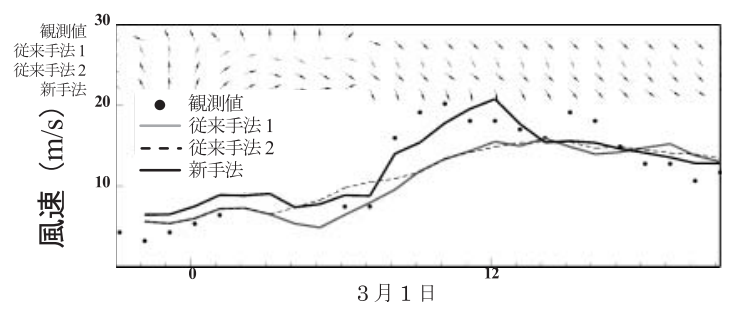

図-11 各手法による風向風速の経時変化 （風向：上部ベクトル）

る手法の確立を目指す必要がある。また，台風事例など 他の現象にも，3DVARを適用し検証する必要がある。

最後に, 本研究の一部は, 科学研究費補助金 20360222 の成果であり，ここに記して謝意を表する。

\section{参 考 文 献}

大澤輝夫 ・竹山剛生 - 安田孝志 (2001) : メソ気象モデルと台 風ボーガスを用いた伊勢湾台風時の風の場のシミュレー ション, 海岸工学論文集, 第 48 巻, pp. 281-285.

金 庚玉 ·李 漢洙・山下隆男 (2005) : ボーガス低気圧を援 用したMM5 と WW3 結合モデルによる冬季日本海の異常 波浪の再現計算, 海岸工学論文集, 第52巻, pp. 176-180.

杉本聡一郎 (2008): 水蒸気および風に関するリモートセンシ ング観測值のメソ気象モデルへのデー夕同化, 電力中央 研究報告, N07033, 20p.

露木 義・ 川畑拓矢 (2008): 気象学におけるデー夕同化, 気 象研究ノート, 第217号, 277p.

中野俊夫 · 大澤輝夫 - 吉野 純 - 益子 涉 - 河合弘泰 - 松浦 邦明 (2005)：台風ボーガスの高度化による数值予報モデ ルを用いた海上風推算手法の精度向上, 海岸工学論文集, 第 53 巻, pp. 1286-1290.

Barker, D.M., W. Huang, Y.-R. Guo, and Q.N.Xiao(2004): Three Dimensional(3DVAR) Data Assimilation System For Use With MM5: Implemental and Initial Results. Monthly Weather Review 132, pp. 897-914.

Parrish,D.F., and J.C. Derbber(1992): The National Meteorological Center's Spectral Statistical Interpolation analysis system. Monthly Weather Review 120, pp. 1747-1763. 